\title{
A Renewed Social Democracy for an 'Age of Internationalism': An Interpretivist Account of New Labour's Foreign Policy
}

\author{
Judi Atkins \\ School of Politics and International Studies \\ University of Leeds \\ Leeds LS2 9JT \\ UK
}

Email: J.R.Atkins@leeds.ac.uk

\begin{abstract}
This paper employs an interpretive approach to explore New Labour's use of social scientific theories in developing its foreign policy. After situating New Labour in the broad tradition of social democracy, it outlines the beliefs that most social democrats shared about the values of internationalism, international community and moral leadership. Taking these concepts in turn, the paper then considers how New Labour modified their content in response to issues raised by 'New Times'. In so doing, it problematizes New Labour's responses by revealing that they drew on ideas taken from complex interdependence theory, communitarianism and democratic peace theory respectively. The paper then examines how these theories, in conjunction with the reformulation of its foreign policy, influenced New Labour's transformation of the three values, before concluding with a brief examination of the dilemmas arising from this process.
\end{abstract}

Short title: New Labour's Internationalism

Keywords: interpretivism; New Labour; foreign policy; internationalism

Word count: 8,784 (inc. references and endnotes) 


\section{A Renewed Social Democracy for an 'Age of Internationalism': An Interpretivist Account of New Labour's Foreign Policy}

New Labour's philosophy and programme were fundamentally shaped by its belief in globalisation. This process is associated with the expansion of world financial markets, the increased mobility of capital and the intensification of global trade competition. At the same time, 'travel, communications and culture are becoming more and more international, shrinking the world and expanding taste, choice and knowledge' (Blair 1996). These developments were accompanied by dramatic social changes as the influence of custom declined, cultural and family ties loosened, and previously stable communities collapsed (Driver and Martell 2006, 22). For the architects of New Labour, these 'New Times' posed a significant challenge to the social democratic tradition, in response to which they advocated the 'Third Way'. This programme, Tony Blair explained, stood for a 'modernised social democracy, passionate in its commitment to ... the goals of the centre-left, but flexible, innovative and forward-looking in the means to achieve them' $(1998,1)$.

In New Labour's narrative of 'New Times', globalisation was represented as an 'unstoppable force' to which governments needed to adapt (Blair 2010, 689). While this representation played an important role in the rationalisation of New Labour's programme of modernisation and renewal (McGrew 2004, 141), it is worth noting that 'globalisation' is not a given fact, but a contingent concept that can be constructed in a variety of different ways. ${ }^{1}$ The desire to expose the contingency of social life is central to the interpretivist approach of Mark Bevir and Rod Rhodes. As Bevir puts it, 'no practice can fix the ways in which its participants will act, let alone how they 
will innovate within it in response to novel circumstances' $(2005,21)$. One way in which politicians can modernise a practice is by drawing on 'rationalities' taken from the social sciences. Rationalities are defined as 'the scientific beliefs and associated technologies that govern conduct; [the term] captures the ways in which governments and other social actors draw on knowledge to construct policies and practices' (Bevir and Rhodes 2010, 96-97). This process may necessitate a modification of the values associated with the traditions against the backdrop of which agents operate (Bevir $2005,63)$, which in turn can give rise to new dilemmas and challenges.

Despite the insights it can offer, interpretivism has not been widely used in the analysis of UK foreign policy. This is evident from a survey of the vast literature on New Labour's foreign policy, which typically focuses on case studies ${ }^{2}$ and employs a variety of methods, including discourse analysis (Fairclough 2000, ch. 6), agential explanations (Dyson 2009; Hoggett 2005), structural analysis (Kettell 2006) and security studies (Bluth 2004). The present paper seeks to contribute to this debate by using an interpretive approach to show how New Labour's construction of, and response to, 'New Times' relied on rationalities taken from the social sciences. ${ }^{3}$ I begin by locating New Labour in the broad tradition of social democracy and sketching the beliefs that many social democrats shared about the values of internationalism, international community and moral leadership. Taking these commitments in turn, I consider how New Labour modified them in response to the challenges of 'New Times'. In so doing, I problematize these responses by demonstrating that they drew on complex interdependence theory, neocommunitarianism and democratic peace theory respectively. I then show how these rationalities, in conjunction with New Labour's reformulation of its foreign 
policy, led it to modify the content of the three values, before concluding with an examination of the dilemmas arising therefrom.

\section{New Labour and social democracy}

The New Labour project was a contingent reworking of the dominant tradition within social democracy in response to the socio-economic challenges of 'New Times'. While this dominant tradition has its roots in ethical socialism, Fabianism and liberalism, writes Bevir, it is important to note that social democracy contains a number of competing strands $(2005,135)$. Thus, 'when we invoke it, or for that matter New Labour [or] Old Labour ... we simplify complex patterns of beliefs and loyalties in order to interpret broad political movements'. Nevertheless, Bevir continues, we can identify in general terms a social democratic tradition that views human existence and flourishing as possible only within a community $(2005,43)$. This belief finds expression in Blair's claim that 'we all depend on collective goods for our independence; and all our lives are enriched - or impoverished - by the communities to which we belong' $(1998,4)$.

Since its inception, the Labour party's approach to foreign policy has been founded on a belief in internationalism. This belief incorporated themes from radical liberalism, as well as Fabian, Nonconformist and Christian socialist ideas, and can be broadly defined as 'the desire to transcend national barriers in order to find solutions to international issues' (Vickers 2004, 193). However, the breadth of this concept ensures that it can be interpreted in a variety of ways, with different definitions predominating at different times in Labour's history. As such, internationalism does 
not offer decisive policy prescriptions, and so can be invoked to justify 'nonintervention in the pursuit of peace, or intervention for military or humanitarian means' (Vickers 2004, 194). This concept can be disaggregated into three commitments, namely internationalism, international community and moral leadership, and I now consider them in turn.

As Rhiannon Vickers correctly points out, Labour's conception of internationalism draws on the liberal notion that although anarchy is the basic condition of the international system, states nonetheless have certain interests and values in common. For this reason, many social democrats believed it was possible to reform the system through the construction of international organisations, whose role was to 'regulate economic, political and military relations between states'. They also believed that an important function of these institutions was to provide collective security against aggression. As such, most social democrats rejected the balance of power and secret bilateral treaties, viewing them as 'self-defeating in terms of generating conflict' (2004, 194).

Throughout Labour's history, social democrats have disagreed over the means for achieving their internationalist goals. On the issue of security, for instance, Attlee, Bevin and others sought to further Britain's national interest through closer ties with the USA, a relationship that was eventually institutionalised through NATO. However, many on the left of the party opposed this decision, believing instead that 'internationalism and international solidarity meant working with Russia, not capitalist America'. This disagreement remained unresolved, and, by the end of the Cold War, the rift between left and right had hardened into 'a division between 
Atlanticists and those suspicious of the USA, which continues to this day' (Vickers 2004, 12; see also Rosen 2005, 141, 143-146). Similarly, in the debate over Britain's entry into the Common Market, pro-Europeans argued that internationalism meant closer ties with Europe (Mackintosh 1971, in Rosen 2005, 299), while Eurosceptics believed Britain's future instead lay with the Commonwealth (Gaitskell 1962, in Brivati 2004, 235). This issue also split the party, and indeed was the main reason why some pro-European Labour MPs broke away and formed the SDP in 1981 (Brivati 2004, 237).

A second theme within Labour's version of internationalism is the idea that states belong to an international community. For this reason, social democrats held that 'each state has a responsibility to work towards the common good of the international system, to work in the "international" interest rather than purely in what it perceives to be its national interest' (Vickers 2004, 194). Many within the Labour Party also believed in the existence of universal moral values such as democracy and human rights. Because they saw domestic and foreign policy as 'inextricably linked, and as impacting on each other', these social democrats claimed the values that governed their conduct at home must be reflected in their dealings with other states. ${ }^{4}$ On this basis, they endorsed a democratic foreign policy that was founded on openness and co-operation (Vickers 2004, 197-198).

In practice, Labour violated its commitment to a democratic foreign policy on several occasions, including the secret negotiations on Britain's nuclear weapons strategy in 1947 (Vickers 2004, 199). Arguably the most shocking example is the 1966 agreement authorising the depopulation of the island of Diego Garcia to make way for 
a US military base, which was signed without the approval of Parliament or Congress. In return for its co-operation, the US government allowed Britain to purchase Polaris nuclear missiles at a reduced cost (Vine 2009, 7, 87). While this agreement manifested the Atlanticist tendency within Labour, it also reflected the belief that the party needed to appear strong on defence in the eyes of the public (Vickers 2004, 203), on which basis the Wilson government retained its predecessor's commitment to Polaris. The latter decision brought Wilson and his supporters into direct conflict with Labour's anti-militarist wing, who viewed unilateral nuclear disarmament as a means of providing moral leadership in the world. This is the third theme within Labour's internationalism and I examine next.

Labour's commitments to universal moral values and the pursuit of the international as well as the national interest were closely linked to its belief that Britain could act as a moral leader. In Vickers' words, this idea

Reflects the context within which the Labour Party developed, as well as its tendency to have a missionary zeal to reform and shape the world in its likeness, which has sometimes been at odds with its commitment to working through international institutions' $(2004,197)$.

As we would expect, the precise nature of Britain's moral leadership role was contested, with different approaches achieving prominence at different times in Labour's history. This moral imperative has been manifested variously as commitments to international disarmament and arms control and, in the Cold War era, as the belief that Britain could act as a 'bridge' between East and West, mediating in disputes between the two sides (Vickers 2004, 196-197). It has also been interpreted as the provision of international aid and debt relief for developing countries. While it 
is important to recognise these diverse interpretations of moral leadership, it is nonetheless possible to identify two recurring themes, namely an anti-militarist impulse and a commitment to tackling poverty and oppression across the world.

It is clear from the discussion so far that there are several competing traditions within the Labour Party, and that their contrasting interpretations of its internationalist principles have created deep divisions within it. Indeed, the recognition of this diversity helps us to explain such major shifts in Labour policy as that from an anti- to a pro-European position in the 1980s. In the following three sections, I take Labour's internationalist commitments in turn and show how New Labour's response to the challenges of 'New Times' transformed the tradition of social democracy. In so doing, I problematize this response by demonstrating that it relied on ideas taken from the social sciences. I also consider how New Labour's reformulation of its foreign policy entailed changes in the content of the values of internationalism, international community and moral leadership.

\section{Internationalism}

Labour's belief in internationalism endured throughout the post-1945 era, with a succession of party leaders expressing their support for the United Nations and the NATO alliance (e.g. Attlee 1951; Wilson 1964, 1970; Kinnock 1985; Smith 1992). It also persisted in the early 1980s when, notwithstanding his controversial commitment to withdraw Britain from the Common Market, Michael Foot promised that Labour would fulfil 'our international obligations and our obligations as socialists to other people in other lands' (1982). Following its defeat in the 1983 general election, the 
party reverted to a more traditional stance, as evidenced by its 1987 manifesto commitment to work with the UN and the Commonwealth to promote freedom and reduce conflict across the world (Labour Party 1987). By the early 1990s, however, the world was facing new transnational challenges following the collapse of communism. Blair identified the most obvious of these issues as 'security and environmental protection', and he argued that 'our global governing institutions [had] not adapted sufficiently fast in response'. As a result, he continued, it was necessary to 'deepen and extend [the EU, NATO and the WTO], not reject them' $(1998,18)$.

Throughout its term of office, New Labour's foreign policy was premised on the claim that globalisation had produced a new world order in which nation states were interdependent. As a result of this interdependence, Blair argued, economic, security and political developments in other countries can create a ripple effect that is felt around the globe. For instance:

Financial instability in Asia destroys jobs in Chicago and in my own constituency in County Durham. Poverty in the Caribbean means more drugs on the streets in Washington and London. Conflict in the Balkans causes more refugees in Germany and here in the US (1999).

Thus, Blair continued, 'we live in a world where isolationism has ceased to have a reason to exist'; in short, 'we are all internationalists now, whether we like it or not' (1999). This belief was shared by Robin Cook who, in launching his Mission Statement for the Foreign and Commonwealth Office, declared that 'this is an age of internationalism ... We live in a world in which nation states are interdependent' (1997). Similarly, Cook's successor, Jack Straw, asserted that 'our party's 
commitment to internationalism means we are best placed to confront the challenges of our complex, interdependent world' (2003).

For New Labour, the rise of interdependence brought the recognition that the Britain's interests were inextricably linked to those of other states. After all, Blair claimed, 'as problems become global - competitivity, changes in technology, crime, drugs, family breakdown - so the search for solutions becomes global too ... We are all coping with the same issues' (1999; see also Cook 1997, Straw 2003). On this basis, New Labour proposed to manage the insecurities generated by 'New Times' by 'working within and through ... existing multilateral organisations of global and regional governance, from the WTO to the EU' (McGrew 2004, 143). Thus, on the environment, Gordon Brown argued that 'together the UN and the World Bank must work to create a global environmental presence that exhorts, incentivises, researches and monitors [climate] change and most of all is in a position - alongside the private sector - to invest in change' (2006). Likewise, Clare Short claimed that 'New Times' demanded global solidarity, and in particular 'a strengthening not a weakening of our global institutions and a stronger commitment to development and the reduction of poverty' (2001, quoted in McGrew 2004, 143).

Like traditional social democracy, New Labour emphasised the importance of international organisations for the preservation of global order. Cook identified NATO as the cornerstone of Britain's security, and he argued that its ongoing enlargement must be managed to ensure that the process both strengthened the Alliance and reduced the tensions between East and West (1997). At the same time, Cook and Blair expressed their commitment to Europe, claiming that membership of 
the European Union would strengthen Britain's relationship with the US. It was thus that New Labour 'squared the circle of internationalism, European unity and the Anglo-American relationship during its first term of office' (Coates, Krieger and Vickers 2004, 12-13).

The Kosovo crisis of 1999 marked a turning point, as it led Blair to urge 'a critical examination of ... the changes we need to make in organisation and structure' of NATO once operations were concluded. More specifically, he argued, Kosovo underlined the need for the international community to take decisive action against dictators like Slobodan Milošević, who had 'brought calamity on their own peoples', and thus to deter others - such as Saddam Hussein - from doing the same. This was particularly important, Blair continued, because if NATO's campaign in Kosovo had failed, 'the next dictator to be threatened with military force may well not believe our resolve to carry the threat through' and international security could be compromised as a result (1999).

Following the attacks of 11 September 2001, Blair claimed that the major security threat in an interdependent world was not conventional warfare between nation states, but 'chaos' (2002a). He identified the two main causes of chaos as terrorism and rogue states in possession of weapons of mass destruction (WMD), and argued that the link between them was becoming stronger, that there was a 'real and present danger' of terrorist organisations acquiring WMD (2003a). Of particular concern was Saddam Hussein's Iraq, which had continued to develop WMD in defiance of UN resolutions and, as such, posed a grave threat to the stability of the Middle East. For Blair, it was vital that the international community confront this danger directly, or 
risk undermining the credibility of the UN. After all, he claimed, 'weakness in the face of a threat from a tyrant is the surest way not to peace but to war' (2003a). In the same vein, Straw told Parliament on the eve of the invasion that the consequences of inaction would be 'an undermining of the authority of the United Nations, the rearmament of Iraq, a worsening of the regime's tyranny, an end to the hopes of millions in Iraq, and a message to tyrants elsewhere that defiance pays' (Hansard 18 March 2003, vol. 401, col. 902).

In accordance with the precedent set by Kosovo, Britain went into Iraq as part of the US-led 'coalition of the willing'. This decision was opposed by many on the left of New Labour, who argued contra the party leadership that such action would harm the national interest by undermining the authority of the UN. As Cook explained, 'Britain is not a superpower. Our interests are best protected, not by unilateral action, but by multilateral agreement and a world order governed by rules' (quoted in Coates and Krieger 2004, 85). Short's assessment of the situation was more direct: 'there's a risk of a divided world, with a weakened UN and we shouldn't be doing it like this' (BBC 2003). Thus, social democrats on both sides of the debate retained Labour's traditional belief in strong international organisations, though they were deeply divided over how this goal was to be achieved.

In the past, many social democrats emphasised collective security and international organisations as the means to promote peace. However, Blair and his followers believed that in an interdependent world, where conventional warfare is no longer the principal threat to national security, a new strategy was required. To this end, they rejected the formal multilateralism associated with traditional social democracy in 
favour of a more ad hoc approach. Although New Labour did not employ this informal multilateralism in the sphere of trade and finance, notes Paul Williams, it was clearly evident in its international security policy after the Kosovo conflict. The emergence of this new strategy, Williams continues, was facilitated by Blair's belief that UN authorisation was not required for humanitarian intervention, and the New Labour government's acquisition of several ad hoc coalitions of the willing through which it could conduct military action $(2004,926)$. As such, Blair and his supporters altered the content of the traditional social democratic value of internationalism as an unintended consequence of the policies they enacted in response to the challenge posed by Kosovo. Another key influence was complex interdependence theory, as I demonstrate next.

According to Stephanie Lawson, 'globalisation produces a system of complex interdependence where decisions "here" reverberate "there" with significant consequences' $(2002,169)$. The theory of complex interdependence was first advanced by Robert Keohane and Joseph Nye in the 1970s as a response to neorealism, and describes a world in which levels of economic, social and environmental globalism are increasing and military globalism is in decline. Under these conditions, Nye claims, many transnational issues, such as climate change and the arms trade, can only be addressed through international co-operation. Such collective action may take the form of 'transgovernmental policy co-ordination', in which states work together, often through international organisations, to tackle common problems $(2004,154,75$, 166). 
New Labour's modification of the social democratic commitment to internationalism drew on ideas from complex interdependence theory. This influence is clear in Blair's statement that 'it is very rare today that trouble in one part of the globe remains limited in its effect. Not just in security, but in trade and finance ... the world is interlocked' (2002b). Complex interdependence theory also reinforced New Labour's belief that international co-operation offered the best means of addressing global problems. However, New Labour's acceptance of the reality of interdependence also brought the realisation that transnational threats could not be tackled by conventional means. This led Blair and his supporters to modify the value of internationalism by advocating the use of ad hoc coalitions in situations where multilateralism based on formal organisations was ruled out. Given Blair's claim that this approach would uphold the authority of institutions such as the UN, we can say that he maintained the traditional social democratic commitment to strong international organisations, though he sought to realise it through very different means.

\section{International community}

The Labour Party's approach to foreign affairs has always been guided by a belief in universal moral values. For this reason, it held that its ethical principles should be reflected in its domestic and international policy alike. This commitment was present in Wilson's address to his 1968 party conference, which took place six months after Enoch Powell delivered his controversial 'rivers of blood' speech in Birmingham. Here, Wilson identified human rights as 'the central theme of this Government's actions from the day we took office'. To support this claim, he described how he had 
challenged the Conservatives over their racist general election campaign in Smethwick, and how his government had 'issued, in the strongest terms, a warning against racial extremists in Rhodesia ... a warning on which we had to act'. After all, Wilson continued, 'the struggle against racialism is a world-wide fight. It is the dignity of man for which we are fighting. If what we assert is true for Birmingham, it is true for Bulawayo' (1968).

In addition to universal values, Labour's belief in international community often entailed a commitment to international co-operation. This strategy gained momentum as the British Empire declined and, in 1977, James Callaghan described how his government had worked with the US, Europe and the international community to launch an initiative that would pave the way for an 'an independent and non-racial Zimbabwe under majority rule in 1978'. The Labour government thus rejected the 'philosophy of inferiority from the cradle to the grave', whether in Britain or abroad (Callaghan 1977). Labour's commitment to the idea of an international community was subsequently reinforced by the perceived intensification of globalisation, with Cook arguing that, in an interdependent world, 'foreign policy is not divorced from domestic policy but a central part of any political programme' (1997). As a result, Blair claimed, 'national interest is to a significant extent governed by international collaboration' (1999).

As we would expect, Blair's conception of international community was founded on a belief in the interdependence of states. On this basis, he argued that 'just as within domestic politics, the notion of community - the belief that partnership and cooperation are essential to advance self-interest - is coming into its own; so it needs to 
find its own international echo' (1999). This statement invoked the social democratic idea that the well-being of one state is inextricably bound up with that of others, and that the Labour Party should promote the interests of the international community as well as those of Britain. Blair's notion of international community also drew on the idea that there are universal moral values, which he identified as human rights, an open society, liberty, and the rule of law. For Blair, it was in Britain's national interest to establish these principles abroad because shared values promote community cohesion and reduce conflict. In this way, he claimed, 'values and interests merge' (1999).

Conor Gearty observes that, from Blair's perspective, the September 11 attacks vindicated the doctrine of the international community $(2003,2)$. Indeed, Blair subsequently argued that these events led the international community to recognise that the world needs order, and that progress is possible only under conditions of security and stability. On Blair's view, the prerequisites for these conditions were the values of democracy, justice and freedom. 'Where these are strong', he argued, 'the people push for moderation and order. Where they are absent, regimes act unchecked by popular accountability and pose a threat; and the threat spreads'. As a result, Blair concluded, 'the promotion of these values becomes not just right in itself but part of our long-term security and prosperity' (2002b).

In responding to the challenges posed by the events of $9 / 11$, Blair modified the social democratic idea of international community. This response contained themes drawn from New Labour's conception of domestic society, which in turn was based on the primary precept of Third Way politics: 'no rights without responsibilities' (Giddens 
1998, 65). For New Labour, this principle was intended to rectify the excessive emphasis on rights over duties that characterised post-war social democracy. As Blair explained, duty 'defines the context in which rights are given. It is personal; but it is also owed to society' (1995). Thus, in New Labour's thinking, rights were no longer seen as the automatic entitlement of all citizens as they were by earlier social democrats; rather, they had become conditional on the performance of specific duties (Bevir 2005, 68).

This conditional view of rights was implicit in Blair's conception of international community. Here, each state must perform a number of duties as a member of the international community, among which are obligations to uphold the human rights of its citizens and to respect the autonomy of other states. If a state fulfils these responsibilities, then it receives in return the right to self-determination, and thus is granted protection under the principle of non-intervention (Atkins 2011, 163-164; Coates and Krieger 2004, 21; McGrew 2004, 144). However, if a state refuses to act responsibly, it can be compelled to do so through measures such as economic sanctions and military force. As a consequence, writes Justin Rosenberg, 'the absolute nature of state sovereignty is becoming ... conditional upon the state concerned observing certain basic standards of human rights [and] democracy' (2000, 19).

New Labour's second modification of the social democratic concept of community was 'the aspect of exclusion that follows from the new stress on the obligations of the recipients of the recipients of social rights' (Bevir 2005, 68). As we have seen, New Labour endorsed a contractual notion of citizenship, in which rights are conditional on 
the performance of duties. One implication of this approach was that if an individual refused to act responsibly, and so failed to keep their side of the bargain, then they had forfeited their rights and were therefore 'socially excluded'. This idea was evident in New Labour's welfare-to-work programmes, where participants had a responsibility to accept offers of work or training - or to stop claiming benefits. Those who refused to participate in the schemes were no longer viewed as full citizens, their exclusion 'implicit in the fact that they [were] to be denied some of the rights given to other citizens' (Bevir 2005, 68).

This aspect of exclusion was present in Blair's conception of international community, where nations who failed to fulfil their obligations were classed as 'rogue states'. As Blair explained, such states are 'answerable to no democratic mandate, so are unrestrained by the will of ordinary people. They are extreme and inhumane. They detest and fear liberal, democratic and tolerant values' (2003b). Because 'rogue states' do not share 'our values' and, moreover, refuse to perform the duties ascribed to them, they were deemed to be excluded from the international community. For Blair, the best way of dealing with these states was to instil in them 'our values', and thus bring them back into the international community. This, he believed, would make the international community stronger and more cohesive, which in turn would increase global security and stability (2002b).

The value of community was Blair's guiding concept, and indeed was 'presented as New Labour's "Big Idea", the idea that would renew the party's electoral appeal' (Goes 2004, 111). To give content to this notion, New Labour turned once more to the social sciences, and in particular to neocommunitarianism. Neocommunitarians 
encourage the recognition that individuals owe certain obligations to their community, and that the community has a duty to ensure that both rights and responsibilities are upheld. They thus define a good society as one in which individual autonomy is balanced with the common good, and where 'the right to be left alone, to have one's home be one's castle, does not hold for those who violate generally held moral standards'. Likewise, nations are seen as members of an international community who 'share ties, moral commitments, at least a limited set of moral norms, a concern for the common good, and responsibility for and to the community' (Etzioni 2006, 78). These responsibilities are balanced with rights, so states who fulfil their international obligations will receive in return the privileges of sovereignty. Conversely, states who fail to abide by international moral norms may be subject to intervention. State sovereignty is therefore rendered conditional, with nations treated not as autonomous actors, but as 'members of an international community who are expected to adhere to that community's evolving norms regarding what is considered legitimate' (Etzioni 2006, 72).

Blair's reworking of the concept of international community incorporated themes derived from neocommunitarianism. In particular, he endorsed the notions that rights are accompanied by responsibilities, and that state sovereignty is conditional on the performance of these duties. These ideas are evident in his belief that Iraq was acting irresponsibly by developing WMD and violating the human rights of its citizens, and that the international community therefore had a moral duty to intervene (Blair 2002b). On this contractual view of international citizenship, failing or authoritarian states are excluded from the international community, and Blair believed that Britain should tackle this exclusion by promoting international moral norms, or 'our values'. 
Such action would bring 'rogue states' back into the international community, and thus increase global order and security. This approach was intended to advance both the international and the national interest, and we can therefore say that Blair upheld the social democratic commitment to work towards the common good of the international system, though he employed new means to do so.

\section{Moral leadership}

Over the course of the $20^{\text {th }}$ century, Labour consistently emphasised the potential for Britain to take a leading role in international disarmament and in the tighter regulation of the arms trade (Vickers 2004, 197). Its efforts to exercise moral leadership took a number of forms, which included the use of Britain's influence as a member of the Commonwealth, the UN and NATO (Wilson 1964), its role as a 'bridge' between East and West during the Cold War, support for international negotiations on arms reduction (Callaghan 1980, Labour Party 1987) and, for some on the left of the party, unilateral nuclear disarmament. As Foot explained, 'I do not say [disarmament] would all be done by an example, but I do say that if this country insists on saying "we will sustain our nuclear status whatever happens," then a lot of other countries are going to say exactly the same' (1982).

Alongside arms reduction, Labour's belief in moral leadership was present in its desire to tackle poverty and oppression around the world. In the immediate aftermath of World War II, this commitment was viewed as a means of 'destroy[ing] the soil in which the seeds of war flourish' (Attlee 1950). However, subsequent Labour leaders argued that Britain had a moral responsibility to assist developing countries, and in 
1985 Neil Kinnock told his party conference that 'helping people to provide the means to grow their food, to make their clothes, to find their freedom, is our place in the world'. As we will see below, these two aspects of moral leadership were present in New Labour thinking and, taken together, were intended to 'restore Britain's pride and influence as a leading force for good in the world' (Labour Party 1997).

New Labour's belief in a moral leadership role for Britain reflected both the social democratic commitment to universal moral values and the notion that the domestic and international spheres are intimately connected (Vickers 2004, 197). As Cook famously put it, the New Labour government

Does not accept that political values can be left behind when we check in our passports to travel on diplomatic business. Our foreign policy must have an ethical dimension and must support the demands of other peoples for the democratic rights on which we insist for ourselves (1997).

This approach was motivated by the belief that it was in the national interest to promote Britain's values abroad. It also expressed a desire to win the respect of the international community for Britain's contribution to peacekeeping and the promotion of democracy around the world, which in turn would restore its international standing (Cook 1997).

An important component of this strategy was New Labour's commitment to provide moral leadership on the issue of arms reduction. To this end, Cook promised that his government would 'give a new momentum to arms control and disarmament'. Indeed, he continued, New Labour had 'already made a start with our joint statement 
with France and Germany to work for a total ban on landmines' (1997). However, New Labour's attempts to give moral leadership in this area soon ran into the perennial problem that the British arms industry was a major employer (Vickers 2004, 202-203). This issue came to a head over the sale of arms to Indonesia in the late 1990s, raising the question of "whether Britain has sacrificed its commitment to human rights on the altar of trade' (Wheeler and Dunne 1998, 861).

New Labour's attempts to provide moral leadership proved more successful in the area of international development. Here, New Labour played a leading role in the international effort to tackle global poverty throughout its term of office, and indeed had achieved the majority of its goals on debt relief by 2005 (Manning 2007, 565). Underpinning this commitment was a belief in solidarity, which reflects the influence of Christian socialism on New Labour's thinking. As Brown explained:

It is precisely because we believe that we have obligations beyond our front doors and garden gates, responsibilities beyond the city wall, duties beyond our national borders, that we are called on to feed the hungry, shelter the homeless and help the sick, whoever they are and wherever they are (1999).

This conception of solidarity and global responsibility was also evident in New Labour's willingness to undertake humanitarian intervention in Kosovo, which it reaffirmed by deploying troops to Sierra Leone in 2000 .

The arms control and humanitarian strands of Labour's concept of moral leadership came together in Blair's argument for intervention in Iraq. In making this case, Blair emphasised the growing possibility that Saddam might diffuse his WMD technology 
to terrorist organisations, which would lead to widespread chaos and disorder. As such, action was needed to prevent the proliferation of WMD. Blair also justified the invasion by reference to the suffering of the Iraqi people under Saddam's regime, telling his listeners that 'the death and torture camps, the barbaric prisons for political opponents, the routine beatings for anyone or their families suspected of disloyalty are well documented'. Such brutality should not be allowed to continue, Blair claimed, and the international community therefore had a duty to intervene on humanitarian grounds (2003a).

For Blair, the solution to both of these problems was to oust Saddam and to 'help Iraq move towards democracy' (2003c). Not only would democratisation benefit the Iraqi people by establishing human rights and the rule of law, Blair argued, but it would 'bring Iraq back into the international community where it belongs, not languishing as a pariah' (2002c). In the same vein, Straw envisaged post-Saddam Iraq as 'a free, democratic and prosperous society, which can deliver for its people and take its rightful place in the community of nations' (2003). Democratisation would thus enable Iraq to share in the goods of community membership, while advancing the interests of the international community through the promotion of global security. As Blair put it, 'a stable democratic Iraq, under the sovereign rule of the Iraqi people, is a mortal blow to [the terrorists'] fanaticism', and so 'the dangers of the threat we face will be diminished' (2004).

Blair's decision to democratise Iraq using military means constituted a reworking of the social democratic value of moral leadership. In the past, many social democrats shared a 'suspicion of the use of force as a foreign policy instrument', which was 
founded on a belief in anti-militarism (Vickers 2004, 201). However, the Kosovo crisis led Blair to believe that 'in protecting and advancing universal principles of justice the claims of national sovereignty could not automatically take precedence' (McGrew 2004, 144), and that Britain could offer moral leadership by undertaking humanitarian intervention through ad hoc coalitions. This interpretation proved controversial, given that some New Labour figures, including Brown and Short, believed that Britain's leadership role lay primarily in the area of international development. Others, such as Michael Meacher, held that Britain should act as a moral leader on environmental matters and in the fight against climate change. So, although many within New Labour agreed that Britain should provide moral leadership to the world, they were deeply divided over how this should be achieved.

Following the September 11 attacks, Blair asserted that New Labour had a unique opportunity to 're-order this world around us' (2001). This desire to remake the world in its own image reflected a longstanding tendency within the Labour party, which found ultimate expression in the democratisation of Iraq. However, it also conflicted with Labour's commitment to working through international organisations, leading Blair to argue that, in the wake of Iraq, Britain's role was to 'construct a consensus behind a broad agenda of justice and security and means of enforcing it'. In practical terms, he continued, this meant

Getting the UN to understand that faced with the threats we have, we should do all we can to spread the values of freedom, democracy, the rule of law, religious tolerance and justice for the oppressed, however painful for some nations that may be (2004). 
For Blair, therefore, Britain's moral leadership role lay in persuading the UN that the democratisation of 'rogue states', through forcible means if necessary, was in the international interest. He was influenced in this by democratic peace theory, which I discuss below.

As Christopher Layne notes, democratic peace theory makes two key claims, the first of which is that democracies never - or at least very rarely - wage war with other democracies, though they are prepared to fight non-democratic states. The second claim is that "when democracies come into conflict with one another, they only rarely threaten to use force, because it is "illegitimate" to do so' (1994, 7-8). Underpinning both of these statements is the idea that the (near) absence of war between democracies is explicable by reference to the norms and values enshrined in their political systems. Although democratic peace theory has been criticised by scholars (e.g. Spiro 1994, Rosato 2003), it received an enthusiastic reception in the US, where many commentators have argued that America's post-Cold War foreign policy should be based on the promotion of democracy abroad (Layne 1994, 46).

We can identify themes taken from democratic peace theory in New Labour's interpretation of moral leadership. The most obvious of these is evident in Jack Straw's assertion that 'no two full democracies have ever made war on each other astonishing, but true' (2005). Blair and his supporters also adopted the notion that the absence of conflict between democracies stemmed from their political values. This idea is expressed in Blair's belief that democracy promotion is in the interests of global peace and security. As he told the US Congress, 'the spread of freedom is the best security for the free. It is our last line of defence and our first line of attack' 
(2003d). While this belief influenced Blair's approach to Kosovo, it acquired a new urgency after the events of September 11. In consequence, Blair reframed New Labour's commitment to moral leadership in terms of the need to democratise 'rogue states' such as Iraq. The use of military force to achieve this objective was a departure from the anti-militarist strand of social democracy, though Labour's traditional belief in the necessity of working in the international common good maintained a strong presence in Blair's case for democratisation.

\section{Conclusion}

This paper has employed an interpretive approach to examine the traditions, rationalities and challenges that influenced the development of New Labour's foreign policy. We have seen that New Labour reworked elements of the dominant strand of social democracy in response to issues arising from 'New Times', and that it did so by drawing on three social scientific theories. From complex interdependence theory, it took the ideas that states are becoming increasingly interconnected due to globalisation, and that the best means of addressing global problems is through international co-operation. From neocommunitarianism, New Labour derived an emphasis on responsibilities and shared values as the basis for strong communities, and a conditional view of rights. From democratic peace theory, it took the notion that democracies rarely fight each other, and that democracy promotion is therefore in the interests of global peace and security.

These ideas, together with its reformulation of foreign policy in response to specific challenges, led New Labour to modify the values of internationalism, international 
community and moral leadership. Thus, Blair and his supporters rejected the formal multilateralism traditionally associated with internationalism in favour of a more $a d$ hoc approach, while maintaining a commitment to strong international organisations. Under Blair's leadership, New Labour also reworked its conception of international community, making a nation's sovereignty conditional on its internal arrangements. Intervention in states who failed to fulfil their responsibilities was therefore justified by reference to the international common good. Finally, Blair modified the value of moral leadership to allow forcible democratisation. While this modification departed from the anti-militarist strand of social democracy, it was nonetheless congruent with Labour's traditional enthusiasm for propagating Britain's values around the world. It was also deemed to be in the national and the international interest, on the ground that the democratisation of 'rogue states' would increase global order and stability.

These modifications created a number of tensions between New Labour's internationalist principles. For instance, New Labour's use of informal coalitions, together with its efforts to advance moral leadership through the transatlantic alliance, challenged its commitment to strong international organisations. Further, its willingness to spread democratic values by force supplanted the anti-militarist strand within social democracy, so heralding a return to the imperialism and Atlanticism of the past. It is worth drawing attention to the presence of some of these themes in American neo-conservatism. ${ }^{5}$ Indeed, George W. Bush and his supporters not only advocated 'unilateral action and pre-emptive strikes to secure US interests', but they also drew on democratic peace theory to argue that the democratisation of Iraq was 'vital for stabilising the Middle East and defeating global terrorism' (Gamble and Wright 2004, 210-211, Ish-Shalom 2007-08, 539). The beliefs of the British left thus 
resonated with Bush's interventionist liberal internationalism in a number of important respects (see Thorpe 2008, 271), revealing more common ground between the two positions than their adherents would perhaps care to admit.

\section{References}

Atkins, J. (2011) Justifying New Labour Policy (Basingstoke: Palgrave Macmillan).

Attlee, C. (1950) Speech to the Labour Party Conference, 3 October.

Attlee, C. (1951) Speech to the Labour Party Conference, 1 October.

BBC (2003) Clare Short interview, 10 March. Available at: http://news.bbc.co.uk/1/hi/uk_politics/2836925.stm

Bellamy, A. (2004), 'Ethics and intervention: The "humanitarian exception" and the problem of abuse in the case of Iraq', Journal of Peace Research, 41:2, 131-147.

Bevir, M. (2003) 'Narrating the British State: An Interpretive Critique of New Labour's Institutionalism', Review of International Political Economy, 10:3, 455-480.

Bevir, M. (2005) New Labour: A Critique (London: Routledge).

Bevir, M. and Gains, F. (2011) 'Ideas into Policy: Governance and Governmentality', Policy \& Politics, forthcoming. 
Bevir, M. and O'Brien, D. (2001) 'New Labour and the public sector in Britain', Public Administration Review, 61, 535-547.

Bevir, M. and Rhodes, R.A.W. (2003) Interpreting British Governance (London: Routledge).

Bevir, M. and Rhodes, R.A.W. (2010) The State as Cultural Practice (Oxford: Oxford University Press).

Blair, T. (1995) The Spectator Lecture, 22 March.

Blair, T. (1996) Speech to the Keidanren, 5 January.

Blair, T. (1998) The Third Way: New Politics for the New Century (London: Fabian Society).

Blair, T. (1999) Doctrine of the International Community at the Economic Club, Chicago, 24 April.

Blair, T. (2001) Speech to the Labour Party Conference, 2 October.

Blair, T. (2002a) Speech to the Labour Party Conference, 1 October.

Blair, T. (2002b), Speech at the George Bush Senior Presidential Library, 7 April. 
Blair, T. (2002c) Prime Minister's Iraq statement to Parliament, 24 September.

Blair, T. (2003a) Prime Minister's statement opening Iraq debate, 18 March.

Blair, T. (2003b) Speech to the Labour Party Spring Conference, 15 February.

Blair, T. (2003c) Prime Minister's address to the Nation, 20 March.

Blair, T. (2003d) Speech to the US Congress, 17 July.

Blair, T. (2004) Prime Minister warns of continuing global terror threat, 5 March.

Blair, T. (2010) A Journey (London: Hutchinson).

Bluth, C. (2004) 'The British road to war: Blair, Bush and the decision to invade Iraq', International Affairs, 80, 871-892.

Brivati, B. (2004) 'Internationalism', in R. Plant, M. Beech and K. Hickson (eds), The Struggle for Labour's Soul: Understanding Labour's political thought since 1945 (London: Routledge), 229-244.

Brown, G. (1999) Speech to the General Assembly of the Church of Scotland, 10 May.

Brown, G. (2006) Speech to the United Nations Ambassadors, 20 April. 
Callaghan, J. (1977) Speech to the Labour Party Conference, 4 October.

Callaghan, J. (1980) Speech to the Labour Party Conference, 30 September.

Coates, D. and Krieger, J. with Vickers, R. (2004) Blair's War (Cambridge: Polity Press Ltd).

Cook, R. (1997) Speech on the government's ethical foreign policy, 12 May.

Daddow, O. (2009) 'Tony's war'? Blair, Kosovo and the interventionist impulse in British foreign policy, International Affairs, 85:3, 547-560.

Daddow, O. and Broad, M. (2010) 'Half remembered quotations from mostly forgotten speeches: The limits of Labour's European discourse', British Journal of Politics and International Relations, 12:2, 205-222.

Doig, A. and Phythian, M. (2005) 'The National Interest and the Politics of Threat Exaggeration: The Blair Government's Case for War against Iraq', Political Quarterly, 76, 368-76.

Driver, S. and Martell, L. (2006) New Labour, $2^{\text {nd }}$ edn (Cambridge: Polity Press).

Dyson, S.B. (2009) 'What difference did he make? Tony Blair and British foreign policy from 1997-2007', in T. Casey, (ed.) The Blair Legacy: Politics, Policy, Governance, and Foreign Affairs (Basingstoke: Palgrave Macmillan), 235-246. 
Etzioni, A. (2006) 'Sovereignty as Responsibility’, Orbis, 50:1, 71-85.

Fairclough, N. (2000) New Labour, New Language? (London: Routledge).

Foot, M. (1982) Speech to the Labour Party Conference, 28 September.

Gamble, A. and Wright, T. (2004) 'The Fallout from Iraq', Political Quarterly, 75:3, 209-212.

Gearty, C. (2003) 'How did Blair get here?' London Review of Books, 25:4, 20 February.

Giddens, A. (1990) The Consequences of Modernity (Cambridge: Polity Press).

Giddens, A. (1998) The Third Way: The Renewal of Social Democracy (Cambridge: Polity Press).

Goes, E. (2004) 'The Third Way and the politics of community', in S. Hale, W. Leggett and L. Martell (eds) The Third Way and beyond: Criticisms, futures, alternatives (Manchester: Manchester University Press), 108-127.

HC Deb (2002-03) 401, col. 902.

Held, D., McGrew, A., Goldblatt, D. and Perraton, J. (1999) Global Transformations: Politics, Economics and Culture (Cambridge: Polity Press). 
Hirst, P. and Thompson, G. (1996) Globalisation in Question: The International Economy and the Possibilities of Governance (Cambridge: Polity Press).

Hoggett, P. (2005) 'Iraq: Blair's mission impossible', British Journal of Politics and International Relations, 7:3, 418-428.

Hughes, K. and Smith, E. (1998) 'New Labour - new Europe?' International Affairs, 74:1, 93-103.

Ish-Shalom, P. (2007-08) “"The Civilization of Clashes”: Misapplying the Democratic Peace in the Middle East', Political Science Quarterly, 122:4, 533-554.

Kettell, S. (2006) Dirty Politics: New Labour, British Democracy and the Invasion of Iraq (London: Zed Books).

Kinnock, N. (1985) Speech to the Labour Party Conference, 1 October.

Labour Party (1987) General Election Manifesto. Available at: http://www.labourparty.org.uk/manifestos/1987/1987-labour-manifesto.shtml

Labour Party (1997) General Election Manifesto. Available at: http://www.labourparty.org.uk/manifestos/1997/1997-labour-manifesto.shtml

Lawson, S. (2002) The New Agenda for International Relations: From Polarization to Globalization in World Politics? (Cambridge: Polity Press). 
Layne, C. (1994) 'Kant or cant: The myth of the democratic peace', International Security, 19:2, 5-49.

McGrew, A. (2004) 'Globalisation' in R. Plant, M. Beech and K. Hickson (eds), The Struggle for Labour's Soul: Understanding Labour's political thought since 1945 (London: Routledge), 137-162.

Manning, R. (2007) 'Development', in A. Seldon (ed.), Blair's Britain 1999-2007 (Cambridge: Cambridge University Press), 551-571.

Nye, J.S. (2004) Power in the Global Information Age: From Realism to Globalization (London: Routledge).

Ohmae, K. (1991) The Borderless World: Power and Strategy in the Interlinked Economy. (London: Fontana).

Ohmae, K. (1995) 'Putting global logic first', Harvard Business Review, 73:1, 119125.

Porteous, T. (2005) 'British government policy in sub-Saharan Africa under New Labour', International Affairs, 81:2, 281-297.

Rosato, S. (2003) 'The flawed logic of democratic peace theory', American Political Science Review, 97, 585-602. 
Rosen, G. (2005) Old Labour to New: The dreams that inspired, the battles that divided (London: Politico's Publishing).

Rosenberg, J. (2000) 'Just war and intervention: The challenge of the international for social and political theory', Papers in Social Theory, 5, 2-20.

Scholte, J. A. (1993) International Relations of Social Change (Buckingham: Open University Press).

Smith, J. (1992) Speech to the Labour Party Conference, 29 September.

Spiro, D.E. (1994) 'The insignificance of the liberal peace', International Security, $19: 2,50-86$.

Straw, J, (2003) Speech to the Labour Party Conference, 1 October.

Straw, J, (2005) Speech to the Fabian Society, 10 March.

Thorpe, A. (2008) A History of the British Labour Party, third edn. (Basingstoke: Palgrave Macmillan).

Vickers, R. (2000) 'Blair's Kosovo campaign: Political communications, the battle for public opinion and foreign policy', Civil Wars, 3:1, 55-70. 
Vickers, R. (2004) The Labour Party and the World, Volume 1: The Evolution of Labour's Foreign Policy 1900-1951 (Manchester: Manchester University Press).

Vine, D. (2009) Island of Shame: The Secret History of the U.S. Military Base on Diego Garcia (Princeton: Princeton University Press).

Wheeler, N.J. and Dunne, T. (1998) 'Good international citizenship: A third way for British foreign policy', International Affairs (Royal Institute of International Affairs 1944-), 74:4, 847-870.

Williams, P.D. (2009) 'Who's making UK foreign policy?' International Affairs (Royal Institute of International Affairs 1944-), 80:5, 911-929.

Wilson, H. (1964) Speech to the Labour Party Conference, 12 December.

Wilson, H. (1968) Speech to the Labour Party Conference, 1 October.

Wilson, H. (1970) Speech to the Labour Party Conference, 29 September.

I am grateful to the workshop participants - in particular Mark Bevir, Oliver Daddow and Ian Hall and the two anonymous referees for their comments on earlier drafts of this paper. I also acknowledge the financial support of the Leverhulme Trust (grant no. F/00 3910 - How the Leader Speaks).

${ }^{1}$ Held et al (1999) identify three main positions within the globalisation debate. Sceptics argue that globalisation is not an 'epochal transformation of world affairs', but a 'myth that conceals the reality of an international economy increasingly segmented into three major regional blocs in which national 
governments remain very powerful' (Held et al 1999, 2; see also Hirst and Thompson 1996). In contrast, hyperglobalisers argue that the rise of the global economy has created a 'borderless world' in which nation states are in decline (Ohmae 1991, 1995), while transformationalists view globalisation as a process of economic, social and political change that is fundamentally reshaping modern societies and the global order alike (Giddens 1990; Scholte 1993).

${ }^{2}$ See, for instance, Daddow and Broad 2010 and Hughes and Smith 1998 on Britain's relations with Europe; Manning 2007 and Porteous 2005 on international development; Daddow 2009 and Vickers 2000 on the Kosovo war; and Bellamy 2004 and Atkins 2011, Ch. 9 on the invasion of Iraq.

${ }^{3}$ For a discussion of New Labour's use of 'rationalities' in a domestic context, see inter alia Bevir 2003, 2005; Bevir and O'Brien 2001; Bevir and Rhodes 2003; and the forthcoming special issue of Policy \& Politics, edited by Bevir and Gains. This themed edition explores 'both the processes facilitating the flow of ideas, and the ideas behind a range of policy areas'. These theories include 'institutionalism, communitarianism, network theory and neo-Keynesianism' (Bevir and Gains 2011, forthcoming).

${ }^{4}$ The converse also applied, and Harold Wilson justified his government's anti-racism legislation by arguing that 'it would be hypocrisy to condemn racialism and colour prejudice and apartheid abroad if we tolerate it in Britain - or in our own Party' (1964).

${ }^{5}$ I thank Reviewer 1 for making this point. 